\title{
Illustrative Examples in a Bilingual Decoding Dictionary: An (Un)necessary Component?*
}

\author{
Alenka Vrbinc (alenka.vrbinc@ef.uni-lj.si), Faculty of Economics, \\ University of Ljubljana, Ljubljana, Slovenia \\ and \\ Marjeta Vrbinc (marjeta.vrbinc@ff.uni-lj.si), Faculty of Arts, \\ Department of English, University of Ljubljana, Ljubljana, Slovenia
}

\begin{abstract}
The article discusses the principles underlying the inclusion of illustrative examples in a decoding English-Slovene dictionary. The inclusion of examples in decoding bilingual dictionaries can be justified by taking into account the semantic and grammatical differences between the source and the target languages. Among the differences between the dictionary equivalent, which represents the most frequent translation of the lemma in a particular sense, and the translation of the lemma in the illustrative example, the following should be highlighted: the differences in the part of speech; context-dependent translation of the lemma in the example; the one-word equivalent of the example; zero equivalence; and idiomatic translation of the example. All these differences are addressed and discussed in detail, together with the sample entries taken from a bilingual English-Slovene dictionary. The aim is to develop criteria for the selection of illustrative examples whose purpose is to supplement dictionary equivalent(s) in the grammatical, lexical, semantic and contextual senses. Apart from that, arguments for translating examples in the target language are put forward. The most important finding is that examples included in a bilingual decoding dictionary should be chosen carefully and should be translated into the target language, since lexical as well as grammatical changes in the translation of examples demand not only a high level of knowledge of both languages, but also translation abilities.
\end{abstract}

Keywords: ILLUSTRATIVE EXAMPLES, BILINGUAL DECODING DICTIONARY, SEMANTIC DIFFERENCES BETWEEN SOURCE LANGUAGE (SL) AND TARGET LANGUAGE (TL), GRAMMATICAL DIFFERENCES BETWEEN SL AND TL, TRANSLATION OF EXAMPLES, TRANSPOSITION, CONTEXT-DEPENDENT TRANSLATION, ONE-WORD EQUIVALENT, ZERO EQUIVALENT, IDIOMATIC TRANSLATION

Opsomming: Toeligtende voorbeelde in 'n tweetalige dekoderende woordeboek: 'n (On)nodige Komponent? Die beginsels onderliggend aan die insluiting van toeligtende voorbeelde in 'n dekoderende Engels-Sloveense woordeboek word in hierdie artikel bespreek. Die insluiting van voorbeelde in dekoderende tweetalige woordeboeke kan geregverdig

* This article is an extended and revised version of the paper The Utility of Examples of Use in an English-Slovene Dictionary, presented by Alenka Vrbinc at the AsiaLex 2016 conference, which took place in Manila, Philippines, 1-3 June 2016. 
word deur die semantiese en grammatiese verskille tussen die bron- en doeltale in ag te neem. Onder die verskille tussen die woordeboekekwivalent, wat die mees frekwente vertaling van die lemma in 'n sekere sin verteenwoordig, en die vertaling van die lemma in die toeligtende voorbeeld, moet die volgende uitgelig word: die verskille in woordsoort; konteks-afhanklike vertaling van die lemma in die voorbeeld; die eenwoordekwivalent van die voorbeeld; zero-ekwivalensie; en idiomatiese vertaling van die voorbeeld. Al hierdie verskille word aangespreek en in besonderhede bespreek saam met die voorbeeldinskrywings geneem uit ' $n$ tweetalige Engels-Sloveense woordeboek. Die oogmerk is die ontwikkeling van kriteria vir die seleksie van toeligtende voorbeelde wat die woordeboekekwivalent(e) in 'n grammatiese, leksikale, semantiese en kontekstuele sin moet aanvul. Afgesien hiervan word argumente ook gevoer vir die vertaling van voorbeelde in die doeltaal. Die belangrikste gevolgtrekking is dat voorbeelde wat in ' $n$ tweetalige dekoderende woordeboek ingesluit word, versigtig gekies moet word en vertaal moet word in die doeltaal, aangesien leksikale sowel as grammatiese veranderings in die vertaling van voorbeelde nie net ' $n$ hoë vlak van kennis van beide tale vereis nie, maar ook vertalingsvermoëns.

Sleutelwoorde: TOELIGTENDE VOORBEELDE, TWEETALIGE DEKODERENDE WOORDEBOEK, SEMANTIESE VERSKILLE TUSSEN BRONTAAL (BT) EN DOELTAAL (DT), GRAMMATIESE VERSKILLE TUSSEN BT EN DT, VERTALING VAN VOORBEELDE, TRANSPOSISIE, KONTEKS-AFHANKLIKE VERTALING, EENWOORDEKWIVALENT, ZERO-EKWIVALENT, IDIOMATIESE VERTALING

\section{Introduction}

Although being one of the entry components, illustrative examples are an optional rather than an obligatory element of the microstructure. They have been used in the compilation of dictionaries for a long time: they were introduced into English lexicography as early as 1755 by Samuel Johnson in his Dictionary of the English Language, but they had been used even before that, for example by Arab lexicographers since the 8th century or by Greek and Latin lexicographers since the 16th century (Al-Kasimi 1977: 89). Illustrative examples can be found in monolingual dictionaries, where they follow the definition(s) as well as in bilingual dictionaries, where they appear after the translation equivalent(s). In the metalexicographic literature dealing with this topic, the following questions regarding illustrative examples are often addressed: what distinguishes an example from a sub-entry; what kind of combinations (free, partially fixed, etc.) can be used as examples; which sources of examples should be used; how the choice of a source is related to the type of dictionary and its target users (Adamska-Sałaciak 2006: 493). When including illustrative examples, a range of factors should be taken into consideration: the extent of the use of examples; what role the examples will play in exemplification; where the examples come from (are they taken from a corpus?, are they invented by lexicographers, or are they (at least partially) modified by lexicographers, despite having been extracted from a corpus?); how consistently they will be included in a dictionary; how to strike a balance between authentic corpus material and the goal of lexicographic efficiency (Jackson 2002: 181; Adamska- 
Sałaciak 2013: 226; Krvina 2014: 3). Doubtlessly, the criteria for the inclusion of illustrative examples should be precisely defined before the compilation of a dictionary begins, and all compilers working on the project should stick to these guidelines as strictly as possible throughout work on the dictionary.

The number of examples illustrating the use of a lemma or a certain sense of a lemma cannot be determined in advance, but it can be claimed that that the number of examples depends on the semantic and grammatical complexity of the lexical item in question, since more complex items generally require a greater number of examples (Toope 1996: 167). In a bilingual dictionary covering the vocabulary of two languages from very different cultures, more examples will be needed (Jacobsen et al. 1991: 2788), and the same holds true for bilingual dictionaries intended for encoding, in which more examples are needed than in those intended for decoding (Kromann et al. 1991: 2772). How many examples will indeed be included in a given dictionary is a matter that should be settled by the lexicographers, and their judgement should be based on the findings of various linguistic studies, existing dictionaries and corpora as well as (at least to a certain extent) evidence derived from their own linguistic intuition (Toope 1996: 170).

Bilingual dictionaries, which are discussed in this article, have a double function, since they can be used to serve either the decoding or the encoding function, and this is a point that should be taken into consideration when deciding what kind of illustrative examples to include in a dictionary. In practice, we do not have a set of four bilingual dictionaries to cover the vocabulary of two languages, while serving for either decoding or encoding by native speakers of either language. Consequently, it can be claimed that bilingual dictionaries usually combine the features typical of both encoding and decoding dictionaries, which means that they can be referred to as combined encoding and decoding dictionaries (Jacobsen et al. 1991: 2786). This is why bilingual dictionaries often include information the users do not need to comprehend a text in a foreign language or lack information the users would need to produce a text in a foreign language (Landau 2001: 307).

We should first briefly mention some difficulties encountered when trying to find an appropriate dictionary equivalent for a lemma or a sense of a lemma. Three levels of equivalence are distinguished: semantic (the equivalent should be semantically as close to the lemma as possible), translational (an equivalent offered in a dictionary is insertable in context; the equivalent must be the same part of speech as the lemma) and functional (the equivalent can be appropriate for a specific situational context) (Adamska-Sałaciak 2006: 496). Lexicographers should try to find an equivalent in the target language (TL) that fits as many different contexts as possible, which means it is as context-free as possible (Atkins and Rundell 2008: 503). In many cases, it is not possible to find a universally acceptable equivalent, because in many source language-target language pairs, we are faced with the problem of a systematic mismatch of semantic distribution between the two languages (ibid.: 504). When a universally acceptable equivalent does not exist in the TL, lexicographers can resort to 
the following alternatives: the near-equivalent and the gloss. No translation of a source language (SL) lemma is possible in the case of zero equivalence; in such a case, examples of use should be provided, together with their translation into the TL (Atkins and Rundell 2008: 505-506).

In bilingual dictionaries, illustrative examples are included in the form of a phrase or sentence in the SL that illustrates the use of a single word, compound or idiom, along with its translation (Van Scherrenburg 1990: 10; Al-Kasimi 1977: 96). A contrastive aspect is doubtlessly very much in the foreground, since the same content can be realized syntactically in different ways (Svensén 2009: 150, 155). Therefore, a bilingual dictionary should include illustrative examples that help the users to comprehend or translate a text from a foreign language into their mother tongue (dictionaries for decoding), or to produce sentences or a text in a foreign language, or to translate a text from their mother tongue into a foreign language (dictionaries for encoding). It should be clear that such examples are being used to exemplify the usage of particular senses; they should convey a great deal of information about the actual usage in context (e.g., grammatical correctness, typical collocations, variety of usage and connotation); they should complement or replace a universally acceptable equivalent and offer an appropriate solution if a universally acceptable equivalent cannot be used (for example, when the example is translated contextually) (Atkins and Rundell 2008: 507; Jackson 2002: 130; Landau 2001: 207208; Béjoint 2000: 135).

The next issue that should be addressed is whether or not illustrative examples included in a bilingual dictionary should be translated. Metalexicographers have conflicting opinions regarding this matter. Al-Kasimi (1977: 96) and Zöfgen (1991: 2898) advocate that the examples should be translated, whereas Jacobsen et al. (1991: 2786) and Adamska-Sałaciak (2006: 493-494) believe that that there is no need to translate examples if they are chosen so as to pose no problems for anyone with a basic knowledge of the TL. AdamskaSałaciak (2013: 228; 2006: 494), however, admits that, in certain cases, the examples must be translated into the L2, and she also enumerates some of these cases: when they introduce important exceptions (e.g., the example shows that, in certain circumstances, a different translation equivalent is needed or that the equivalent provided is omitted in translation); when they might be too difficult for the average user to interpret on their own; when the dictionary is targeted at beginners. At the same time, she proposes (2013: 228) that in electronic dictionaries, translation can be made an optional feature, to be switched on and off when needed.

The article discusses in detail the principles underlying the inclusion of illustrative examples in an English-Slovene decoding dictionary. The aim is to develop criteria for the selection of illustrative examples whose purpose is to supplement dictionary equivalent(s) in the grammatical, lexical, semantic and contextual senses. Apart from that, arguments are advanced for translating illustrative examples in the TL (i.e., Slovene in our case). 


\section{Illustrative examples in some existing English-Slovene dictionaries}

In a bilingual dictionary for decoding, the user searches for the equivalent of a particular sense of an unknown word or word combination that s/he has encountered in a text. The question should be posed in what cases it is sensible to include illustrative examples in the entry of a decoding dictionary. It can be said with a high degree of certainty that illustrative examples are not needed if the lemma can be translated by means of the listed equivalents. In Veliki angleškoslovenski slovar Oxford-DZS (The Oxford-DZS Comprehensive English-Slovenian Dictionary), a relatively high number of illustrative examples are included, but a more careful investigation of these examples reveals that many of these could be excluded without detriment to users or to the usability of the dictionary, since they are translated by the dictionary equivalent(s) provided. Figure 1 shows the entries for seismic (adjective), seizure (noun) and seize (verb), and, as can be seen, only the illustrative examples shaded grey by the authors of this contribution should, in fact, be included, since these cannot be translated by the direct insertion of the dictionary equivalents.

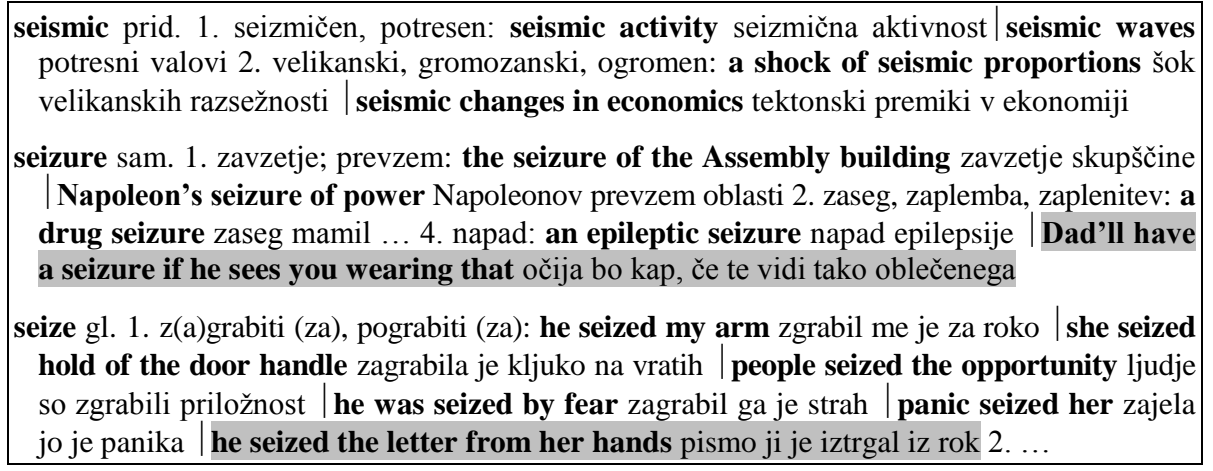

Figure 1: Illustrative examples in Veliki angleško-slovenski slovar Oxford-DZS

Among the unshaded examples, two should be highlighted, i.e., seismic changes in economics and panic seized her, since the translation of the lemma in these examples differs from the equivalent offered in the dictionary, but there is no sound reason for introducing a lexically new equivalent which is synonymous with equivalents provided in the dictionary. The denotation of tektonski is comparable to that of velikanski, gromozanski, and ogromen, and all three equivalents given in the dictionary are insertable in the illustrative example. The same holds true for the translation of panic seized her, where the equivalent provided (i.e., zgrabiti) can be used instead of the verb zajeti. Similarly, the example he seized the letter from her hands can be translated by the verbs given as equivalents, i.e., $z$ (a)grabiti, pograbiti. 
The illustrative examples included in this dictionary are translated without exceptions, but they are not always well chosen and many could be excluded, since the same information is simply repeated. In Collins COBUILD Angleško-slovenski slovar Bridge (Collins COBUILD English-Slovene Dictionary Bridge) and Angleško-slovenski slovar Password (English Dictionary for Speakers of Slovenian Password), which are a cross between a monolingual dictionary and a bilingual dictionary and are intended to bridge the gap between the monolingual and the bilingual dictionary, illustrative examples are not translated. In many cases, however, there is such a huge discrepancy between the dictionary equivalent and the translation of the lemma in the example that the decision not to translate examples should be considered a serious shortcoming, since the user cannot possibly know how to translate the lemma in the example. To illustrate this shortcoming, Figure 2 shows some entries from Angleško-slovenski slovar Password.

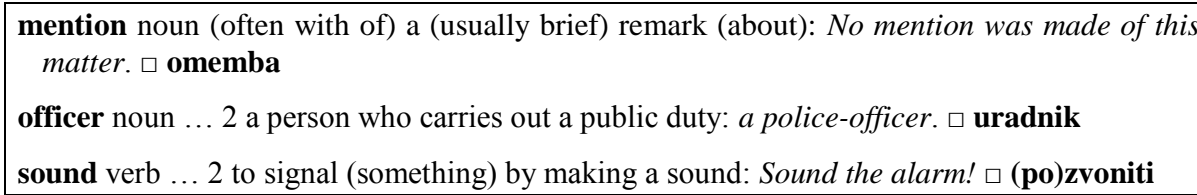

Figure 2: $\quad$ Entries from Angleško-slovenski slovar Password

The noun mention in No mention was made of this matter is not translated by a noun, and it is highly unlikely that an average user would use the method of transposition and translate it by means of the verb omeniti, i.e., Ta zadeva ni bila niti omenjena. As far as sense 2 of the noun officer is concerned, the dictionary equivalent uradnik is in accordance with the definition, but the example policeofficer should be translated into Slovene by a one-word equivalent policist (masculine), policistka (feminine). It should again be pointed out that an average user would not be able to provide the only acceptable translation if this example were not translated. A similar observation can be made in connection with sense 2 of the verb sound, where the equivalent (po)zvoniti matches the definition, but the example Sound the alarm! is an idiom requiring a very specific translation, which can be either idiomatic, i.e., biti plat zvona, or non-idiomatic, i.e., opozoriti/opozarjati na nevarnost.

It is evident from the examples discussed in this section that the illustrative examples included in the existing English-Slovene dictionaries should be chosen far more carefully and should certainly be translated into Slovene, since this is the only way to show the user how the lemma in question can be translated in context correctly and appropriately. In the following section, we will define criteria that should be applied when selecting illustrative examples for a bilingual decoding dictionary. 


\section{Criteria for the selection of illustrative examples for an English-Slovene decoding dictionary}

A bilingual decoding dictionary can include examples illustrating the more general nature of a particular structure, but examples showing contrastive differences between two languages are of even greater importance. Examples are used to illustrate the differences between the listed dictionary equivalent(s) and the translation of the lemma in context or, in other words, the integration of equivalents into a context. They also demonstrate that a lemma should be translated into the TL by a word combination or a structure rather than by a single lexical item (Toope 1996: 96). Among the differences between the dictionary equivalent, which represents the most frequent translation of the lemma in a particular sense, and the translation of the lemma in the illustrative example, the following should be highlighted: differences in the part of speech; context-dependent translation of the lemma in the illustrative example; the one-word equivalent of the example; zero equivalence; and idiomatic translation of the illustrative example. All these differences will be addressed in more detail in this section, together with the sample entries taken from a bilingual English-Slovene dictionary that is in its final stages of completion.

(1) Transposition involving a change in the grammar from SL to TL: the dictionary equivalent corresponds in the part of speech to the lemma, but the lemma used in a specific context is translated by means of another part of speech:

(a) a noun is translated by an adjective:

discretion sam. ${ }^{1}$ obzirnost, diskretnost: be the soul of discretion biti zelo diskreten

(b) a noun used as a premodifier in the illustrative example is translated by an adjective:

nudist sam. nudist, nudistka: nudist beach nudistična plaža

narrow gauge sam. ozki tir: narrow-gauge railway ozkotirna železnica

(c) a noun used in a sentence example is translated by an adverb:

nonsense sam. nesmisel, neumnost, nonsens: It's nonsense to say ... Nesmiselno/Neumno je reči ...

(d) a noun is translated by a verb:

normal sam. normala: Things returned to normal. Stvari so se normalizirale.

(e) a noun which is used in a delexical structure is translated by a verb:

nosebleed sam. krvavitev/krvavenje iz nosa: have a nosebleed krvaveti iz nosa

(f) a noun forming a collocation with a verb is translated by an adjective:

notoriety sam. zloglasnost, razvpitost, notoričnost: gain/win/achieve notoriety postati razvpit 
(g) an adjective is translated by a prepositional phrase:

narcotic prid. ${ }^{2}$ narkotičen: narcotic addiction zasvojenost z mamili

(h) an adjective is translated by an adverb:

typical prid. značilen, tipičen: be typical of sb/sth biti značilno/tipično za koga/kaj

(i) a prepositional phrase is translated by an adverb:

night sam. 1. noč: at night ponoči • by night ponoči • in/during the night ponoči 2. večer: (late) at night (pozno) zvečer

(2) Context-dependent translation of the lemma in the illustrative example: provided there is a gap between the equivalent given in the dictionary and the context-dependent translation of a lemma, illustrative examples are to be included and translated appropriately, thus indicating that the dictionary equivalent is not immediately insertable in any context. At the same time, the user finds possible translations of the lemma in different situations and contexts. Since this is a complex issue, illustrative examples whose translation is context-dependent will be subdivided into three groups:

(a) The translation of the lemma in the illustrative example is based on a listed dictionary equivalent, but the context requires translation with a considerably more specific expression:

average gl. $^{3}$ biti v povprečju, znašati v povprečju: I average about five cups of coffee a day. Na dan spijem povprečno pet skodelic kave. - Pay rises this year averaged $2 \%$. Letos so se plače dvignile povprečno za $2 \%$. - This car averages 40 miles to the gallon. Ta avto porabi povprečno 7 litrov bencina na 100 kilometrov.

As is evident from these examples illustrating the use of the verb average, the verb is often translated by a combination of a specific (contextdependent) verb (e.g., spiti ('drink up'), dvigniti ('rise, increase'), porabiti ('use up')) and the adverb porprečno ('on average').

non-existent prid. neobstoječ: His Italian is non-existent. Ne zna italijansko. • Traffic was almost non-existent. Prometa skoraj ni bilo.

In the entry for the adjective non-existent, illustrative examples are to be included, since the dictionary equivalent neobstoječ is not immediately insertable in many examples. In translating the above illustrative examples, the combination be + non-existent is translated into Slovene by a verb in the negative. For instance, in His Italian is non-existent, be + non-existent in the English sentence is translated into Slovene by a much more specific verb, i.e., the verb znati ('know'). In the second illustrative example (i.e., Traffic was almost non-existent), be + non-existent is translated into Slovene by the negative form of the verb be (i.e., ne biti). 
The examples included in the entry for the noun notch are also worth mentioning, since the Slovene dictionary equivalent stopnja cannot be used in the translation of the illustrative examples:

notch sam. stopnja: be several notches above the others biti precej boljši od drugih $\bullet$ Her spirits lifted a few notches. Njeno razpoloženje se je bistveno izboljšalo • raise one's voice by a notch malo privzdigniti glas

The translation of notch in the above examples depends on the premodifier expressing a level of intensity: several and a few express a higher level, whereas the indefinite article $a$ in the last example implies a lower level. Accordingly, the examples are translated by an appropriate adjective/ adverb in combination with a verb which is semantically equivalent to the verb in the English example.

(b) The lemma in the illustrative example is translated by using the method of expansion, i.e., by adding an entire context:

teeming prid. mrgoleč, vrveč: teeming station postaja, na kateri mrgoli ljudi

As is clear from this example, the Slovene equivalents correspond semantically as well as morphologically to the English lemma. Nevertheless, in spite of an almost ideal situation, neither equivalent can be employed in the translation of the example, since a translation by means of an adjective is completely inappropriate and unacceptable in Slovene. Consequently, the English participle teeming cannot simply be replaced by one of the Slovene participles (mrgoleč, vrveč); instead, the verb from which the participle mrgoleč is derived should be used. Since this verb is transitive in this context, an object (i.e., ljudje 'people') should be introduced in the translation of the illustrative example; this object, however, is context-dependent. Structurally, the English adjective teeming is translated into Slovene by a relative clause (i.e., na kateri mrgoli ljudi).

thick prid. poln: in the thickest part of the crowd v delu množice, kjer se je trlo ljudi

The above example shows that the superlative form of the adjective thick used as a premodifier cannot be translated into Slovene by the equivalent poln. The Slovene translation is context-dependent, which is reflected in the translation of the English adjective thickest into Slovene by an adverbial clause of place containing the verb treti se ('be thick on the ground') and the noun ljudje ('people'), an element which is absent in the English original.

tile sam. ploščica: carpet tiles tapison v obliki kvadratov

The Slovene equivalent of the English noun tile is ploščica, but ploščica cannot be used in the translation of carpet tiles. In this illustrative example, tile is translated by a prepositional phrase (v obliki kvadratov), the supplement $v$ obliki ('in the form of') is a necessary element, while kvadrat ('square') can 
be semantically linked with ploščica as regards its shape.

(c) One and the same illustrative example can be translated differently depending on context:

tear gl. trgati, strgati, raztrgati: tear a hole in sth narediti luknjo v kaj, strgati kaj

In English, the verb tear ('strgati') collocates with the noun hole ('luknja'). However, in translating actual examples, it can be seen that the translation of the collocation varies. If the collocation tear a hole is used with a noun denoting an item of clothing (e.g., I tore a hole in my jeans/sweater. Strgala sem si kavbojke/jopico.), it is translated by the verb strgati; in another context, the same collocation can be translated as narediti luknjo (e.g., The blast tore a hole in the wall. Eksplozija je naredila luknjo v steni.).

(3) Illustrative examples are translated into Slovene by a one-word equivalent:

nude prid. gòl, nag: nude photograph akt

theatre sam. 1. gledališče, teater: a man of the theatre gledališčnik ... 2. brit. ${ }^{4}$ operacijska dvorana: theatre sister instrumentarka ...

term sam. (strokovni) izraz, têrmin: a term of abuse zmerljivka, psovka

As can be seen, the listed dictionary equivalents and the translations of the examples differ. In all but one case, a one-word equivalent contains a semantic component of the dictionary equivalent $(a k t \rightarrow$ an artistic depiction of a nude body; gledališčnik $\rightarrow$ a person who is actively involved in theatre arts; zmerljivka/psovka $\rightarrow$ a rude, disrespectful, offensive word). The only exception is the example theatre sister, which is translated as instrumentarka, a noun denoting a profession and containing no semantic component of the equivalent operacijska dvorana.

(4) Illustrative examples in the case of zero equivalence (in the dictionary entry marked with the symbol $\varnothing$ ):

have gl. ... $\varnothing:$ He had his head cut off. Obglavili so ga. • He's had his wallet taken. Ukradli so mu denarnico. • We have had our request refused. Zavrnili so nam prošnjo. ...

The causative use of the verb have meaning 'to cause something to be done for you by somebody else' does not have an equivalent in Slovene; consequently, only illustrative examples which are translated correctly and appropriately tell the user how have in this sense can be expressed in Slovene. The translation into Slovene contains the translation of the full lexical verbs in the English illustrative example (cut off = obglaviti; take = ukrasti; refuse = zavrniti); these verbs are (usually) in the third person plural, which here suggests generic or impersonal use.

piece sam. ... $\varnothing:$ a fine piece of work čudovito delo $\bullet$ an interesting piece of research zanimiva raziskava $\bullet$ a piece of advice nasvet ... 
In the sense 'a single item', the noun piece is used in a partitive structure consisting of a partitive (i.e., piece) linked by the preposition of to another noun (work, research and advice). The noun piece is not translated into Slovene, since its only function in the above examples is to make an English uncountable noun countable.

space sam. ... $\varnothing$ : in a short space of time $\mathrm{v}$ kratkem času $\bullet$ in/within the space of three years $\mathrm{v}$ treh letih ...

In one of the senses, the noun space can be defined as 'a period of time'. Owing to the contrastive differences between English and Slovene, space in this sense cannot be translated into Slovene by an appropriate equivalent, thus requiring the inclusion of illustrative examples with proper translations. In the above examples, space is left out rather than translated into Slovene.

used to gl. (za izražanje pogostega ali ponavljajočega se dejanja v preteklosti) $\varnothing$ : Did he use to work here? Ali je delal tukaj? • "Do you play tennis?" "No, but I used to." "Ali igraš tenis?" "Ne, ampak sem ga." • He didn't use to smoke. Ni kadil. • He used to live in Paris. Živel je v Parizu. • You used to go to the cinema a lot, didn't you? Veliko si hodil v kino, ali ne? ...

Dictionary equivalents in Slovene do not exist for certain senses of English auxiliary verbs. In such cases, possible translations into Slovene can only be provided by means of illustrative examples showing these lemmata in context. This also applies to the modal verb used to, whose lack of translation into Slovene should be marked using a certain symbol, such as $\varnothing$ implying zero equivalence. In the above examples, Slovene translations all contain the imperfective form of the full lexical verb in the past tense. However, to make the entry more informative and user-friendly, it is advisable to add a short description of its use, one that can be included in brackets preceding the symbol, i.e., za izražanje pogostega ali ponavljajočega se dejanja v preteklosti ('used to express a frequent or repeated action in the past').

(5) Some examples clearly indicate the more or less idiomatic nature of the word combination in question, but since the word combination (still) does not have the status of a phraseological unit in English, it cannot be included and treated in the idioms section. Therefore, we can find such word combinations mostly included as illustrative examples, and it can often be observed that their translations into Slovene are also idiomatic:

tired prid. sit: sick and tired of sth do vrh glave sit česa/koga

tenuous prid. šibek, negotov: He had but a tenuous hold on life. Njegovo življenje je viselo na nitki.

\section{Discussion}

Illustrative examples in a bilingual dictionary should be selected on the basis of 
contrastive differences between the SL and TL. A lemma is always used in context, which means that, apart from semantic features, collocational, connotative and grammatical limitations should also be taken into consideration.

Although a bilingual dictionary cannot explore all the semantic possibilities of a certain lemma in context (Toope 1996: 98), it should provide equivalents that can be used by the user in speaking and writing as well as in translation; in other words, the first objective of the lexicographer compiling a bilingual dictionary is to find a TL word that fits as many of the contexts as possible and is as context-free as possible (Atkins and Rundell 2008: 503). Although a bilingual dictionary cannot include examples demonstrating all possible context-specific equivalents, it should contain a wide range of examples: examples translated by equivalents that are considered common, but are not listed among equivalents in the dictionary; examples translated by context-specific equivalents; examples translated by adding context-specific items; and examples translated by other translation methods (Toope 1996: 101). Doubtlessly, no dictionary can offer solutions to the translation of a lemma or one of its senses in all contexts, but it should include the information that triggers the user's own intuition and reminds him/her that in specific contexts, other equivalents than the most common ones can be used (Toope 1996: 101).

Transposition is one of the most common reasons for the inclusion of illustrative examples in a bilingual (decoding) dictionary. Transposition is the only translation procedure concerned with grammar and, as Newmark (1988: 88) rightly points out, most translators make transpositions intuitively. As far as an average dictionary user is concerned, the question can be raised whether $\mathrm{s} /$ he can also make a transposition intuitively when s/he comes across an unknown word in context. This may depend a great deal on the level of knowledge of both languages, as well as on an individual's feeling for language. Since lexicographers cannot rely on the ability of each individual user to make an appropriate transposition, examples translated from an SL into a TL and involving transposition are absolutely necessary in a bilingual dictionary.

From a dictionary user's point of view, an even more difficult situation arises if the translation of the lemma in context requires the addition of some elements and changes in the grammatical structure, since individual words are translated in context rather than in isolation. The addition of lexical elements and changes in grammatical structure are usually closely connected and depend on a careful study of the wider context in an SL. Apart from that, certain syntactic, collocational, culture-specific and pragmatic differences always exist between two languages, differences of which the user should be made aware to the greatest extent possible. Illustrative examples represent the only part of the dictionary entry that enables the lexicographer to draw the user's attention to these differences. It should, however, be stressed that illustrative examples should be translated, since lexical and grammatical changes in the translation of illustrative examples demand not only a high level of knowledge of both languages, but also translation abilities that cannot be expected from the user of 
a bilingual dictionary, who is usually not a linguist with translation experience.

In an English-Slovene decoding dictionary, we can find quite a large number of examples translated into Slovene by one-word equivalents. In the SL, these word combinations are often collocations, which are normally included in dictionaries as examples. They have not yet acquired the status of a compound; thus, they are not included as independent lemmata. This can be explained by the relatively low frequency, as demonstrated by various corpora as well as by the failure to perceive them as multi-word lexical items with their own meaning, which means that they have not yet undergone the process of lexicalization. When we check, for example, the frequency of some of the examples mentioned in the previous section under 3), we discover that the example nude photograph has 5 hits in the BNC and 14 hits in ukWaC; similarly, man of the theatre is also not in common use (BNC: 7 hits, ukWaC: 30 hits), and the same applies to theatre sister (BNC: 3 hits, ukWaC: 56 hits) and, to a lesser extent, to term of abuse (BNC: 29 hits, ukWaC: 145 hits).

Zero equivalence is another important criterion for the inclusion of illustrative examples in a bilingual decoding dictionary. If there is no equivalent in the TL, no dictionary equivalents can be offered; consequently, the meaning of a lemma can only be conveyed by means of illustrative examples. Since untranslated examples are of no help to the dictionary user, who is not familiar with the meaning of the lemma in question, the translation of examples is an absolute must.

A dictionary equivalent that is of a more general type does not prove useful when dealing with pseudo-phraseological illustrative examples that require idiomatic translation. This is a strong argument for the inclusion of such examples in a bilingual dictionary, as it is the only way to make the user aware of potential pitfalls and to offer him/her a translation acceptable from the point of view of the TL.

To sum up, the findings of our research investigating the inclusion of illustrative examples in an English-Slovene decoding dictionary clearly show that the dictionary equivalents provided can be semantically and functionally appropriate, without satisfying the criterion of translation equivalence. This is the main reason that illustrative examples should be included to provide the user with all possible translations that are considered acceptable in the TL (cf. Adamska-Sałaciak 2006: 499).

\section{Conclusion}

Our study confirms the importance of including illustrative examples in a bilingual decoding dictionary. Although we limit ourselves to an English-Slovene dictionary, the criteria for the selection of illustrative examples can be applied to the compilation of any bilingual dictionary intended for decoding. Examples should be selected with care to clearly show contrastive differences between the two languages. Examples that can be translated by the immediate insertion of a dictionary equivalent can be regarded as superfluous, since the 
user can translate them without difficulty. Examples that cannot be translated by the given dictionary equivalents without employing changes prove to be very useful if included in a bilingual decoding dictionary, since it is not to be expected that an average dictionary user would be able to comprehend them fully, let alone to translate them suitably and correctly. This leads to the conclusion that it is absolutely necessary and important to translate illustrative examples into the TL. If the examples demonstrating contrastive differences between the two languages are not translated, the user is not made aware of the complex differences between the two languages; consequently, it can be claimed that the dictionary does not fulfil one of its main tasks: to clearly show how two different languages function in everyday use.

To conclude, it is important to adopt the approach of functional lexicography and to seek a compromise solution that would meet the user's needs while simultaneously accommodating a precise lexicographic description.

\section{Endnotes}

1. $\quad$ sam. $=$ noun

2. $\quad$ prid. $=$ adjective

3. gl. = verb

4. brit. $=$ British English

\section{References}

\section{Dictionaries}

Angleško-slovenski slovar Password. 1999. Ljubljana: DZS

Krek, S. (Ed.). 2005. Veliki angleško-slovenski slovar Oxford-DZS. Ljubljana: DZS d.d.

Štern, P. (Ed.). 2000. Collins COBUILD Angleško-slovenski slovar BRIDGE. Ljubljana: DZS.

\section{Other Literature}

Adamska-Sałaciak, A. 2006. Translation of Dictionary Examples - Notoriously Unreliable? Corino, E., C. Marello and C. Onesti (Eds.). 2006. Atti del XII Congresso Internazionale di Lessicografia, Torino, Italia, 6-9 settembre 2006. Volume 1: 493-501. Alexandria: Edizioni dell'Orso.

Adamska-Sałaciak, A. 2013. Issues in Compiling Bilingual Dictionaries. Jackson, H. (Ed.). 2013. The Bloomsbury Companion to Lexicography: 213-231. London/New Delhi/New York/Sydney: Bloomsbury Academic.

Al-Kasimi, A.M. 1977. Linguistics and Bilingual Dictionaries. Leyden: E.J. Brill.

Atkins, B.T.S. and M. Rundell. 2008. The Oxford Guide to Practical Lexicography. Oxford/New York: Oxford University Press.

Béjoint, H. 2000. Modern Lexicography: An Introduction. Oxford/New York: Oxford University Press. Hausmann, F.J. et al. (Eds.). 1991. Dictionaries. An International Encyclopedia of Lexicography. Volume 3. Berlin: De Gruyter. 
Jackson, H. 2002. Lexicography: An Introduction. London/New York: Routledge.

Jacobsen, J.R., J. Manley and V.H. Pedersen. 1991. Examples in the Bilingual Dictionary. Hausmann, F.J. et al. (Eds.). 1991: 2782-2789.

Kromann, H.-P., T. Riiber and P. Rosbach. 1991. Grammatical Constructions in the Bilingual Dictionary. Hausmann, F.J. et al. (Eds.). 1991: 2770-2775.

Krvina, D. 2014. Problematika zgledov v novem slovarju slovenskega jezika (med čim večjo avtentičnostjo in leksikografsko učinkovitostjo). Posvet o novem slovarju slovenskega jezika: Novi slovar za 21. stoletje. Ministrstvo za kulturo 12 February 2014. Available at: http://www.mk. gov. si/fileadmin/mk.gov.si/pageuploads/Ministrstvo/slovenski_jezik/E_zbornik/16-_Domen_ Krvina_-_Problematika_zgledov_v_NSJ.pdf [10 December 2015].

Landau, S.I. 2001. Dictionaries: The Art and Craft of Lexicography. Second Edition. New York/Cambridge: Cambridge University Press.

Newmark, P. 1988. Approaches to Translation. New York: Prentice Hall.

Svensén, B. 2009. A Handbook of Lexicography: The Theory and Practice of Dictionary-Making. Cambridge: Cambridge University Press.

Toope, M. 1996. Examples in the Bilingual Dictionary. Unpublished M.A. Thesis. Ottawa: University of Ottawa. [Online]. Available at: http://www.ruor.uottawa.ca/bitstream/10393/9942/1/ MM15769.PDF [28 January 2016].

Van Scherrenburg, D. 1990. The Arrangement of Information in the General Bilingual Dictionary. Unpublished M.A. Thesis. Ottawa: University of Ottawa. [Online]. Available at: http://www. ruor.uottawa.ca/bitstream/10393/5625/1/MM62335.PDF [10 January 2016].

Zöfgen, E. 1991. Bilingual Learner's Dictionaries. Hausmann, F.J. et al. (Eds.). 1991: 2888-2903.

\section{Corpora}

BNC (https://the.sketchengine.co.uk/bonito/run.cgi/first_form?corpname=preloaded/bnc2;).

ukWaC (https://the.sketchengine.co.uk/bonito/run.cgi/first_form?corpname=preloaded/ukwac3;). 